\title{
CONCEPT OF WALI MUJBIR IN MARRIAGE (LEGAL CRITICISM OF COUNTER LEGAL DRAFT COMPILATION OF ISLAMIC LAW)
}

\author{
Musda Asmara \\ Institut Agama Islam Negeri Curup \\ J. Dr. AK Gani No. 01, Curup Utara, Kabupaten Rejang Lebong, Bengkulu 39119 \\ Email: musdaasmara@iaincurup.ac.id
}

\begin{abstract}
Responding to demands from a group of parties to formalize Islamic law, the Counter Legal Draft Compilation of Islamic Law (CLD KHI) team has compiled a pluralist, democratic, humanist, and gender fair Islamic law text.This manuscript reaps pros and cons during society because it is considered not in line with the values contained in the Qur'an and hadith.Because of the discrepancy between the opinions of most jurists in general with the contents of the CLD-KHI, of course, it will result in the absence of legal certainty in the future. The object of this research is only focused on the concept of walimujbir. The method used in this research is a qualitative method with a descriptive approach, data is collected openly according to what is obtained from primary and secondary sources. The results of this study indicate that the presence of a guardian in a marriage is positioned as a pillar of Marriage. In contrast, in the CLDKHI formulation, a guardian is not required in a marriage. The formulation of Islamic family law reform offered by CLD-KHI is based solely on public logic, local wisdom, and on several perspectives such as democracy, pluralism, human rights, justice, gender equality, and western ideology. In matters of marriage, especially regarding guardians of mujbir, the ideas of CLD-KHI are different and even contradict the common understanding of principles of Islamic teachings and practices.
\end{abstract}

Keywords: Wali Mujbir; Marriage; CLD-KHI

\begin{abstract}
Abstrak: Merespon adanya tuntutan dari sekelompok pihak untuk melakukan formalisasi syariat Islam, maka tim Counter Legal Draft Kompilasi Hukum Islam (CLD KHI) telah menyusun naskah syariat Islam yang pluralis, demokratis, humanis, dan adil gender. Naskah ini menuai pro dan kontra di tengah-tengah masyarakat, karena dianggap tidak sejalan dengan nilai-nilai yang terkandung dalam Alquran dan hadis. Melihat adanya ketidaksesuaian antara pendapat kebanyakan fuqaha secara umum dengan isi CLD KHI, tentunya akan berakibat pada tidak adanya kepastian hukum di masa yang akan datang. Objek penelitian ini hanya terfokus pada konsep wali mujbir. Metode yang digunakan dalam penelitian ini adalah metode kualitatif dengan pendekatan deskriptif, data dikumpulkan secara terbuka menurut apa yang didapat dari sumber primer dan sekunder. Hasil penelitian ini menunjukkan bahwa keberadaan wali dalam pernikahan berkedudukan sebagai rukun nikah. Sedangkan dalam rumusan CLD-KHI, wali tidak diperlukan dalam sebuah pernikahan. Rumusan pembaruan hukum keluarga Islam yang ditawarkan CLD-KHI didasarkan pada logika publik semata, kearifan lokal, dan berdasarkan beberapa perspektif seperti demokrasi, pluralisme, hak asasi manusia, keadilan, kesetaraan gender dan ideologi barat. Dalam masalah pernikahan, khususnya tentang wali mujbir, ide-ide dalam CLD-KHI berbeda dan bahkan bertentangan dengan pemahaman umum dari prinsip ajaran dan praktik Islam.
\end{abstract}

Kata kunci: Wali Mujbir; Perkawinan; CLD-KHI 


\section{Introduction}

The validity of Marriage in Islamic law cannot be separated from the pillars and conditions of Marriage. Rukun is an element attached to legal events or legal acts (e.g., marriage agreements), both in terms of legal subjects and legal objects that are part of legal acts or legal events (marriage agreements) when the legal event takes place. The pillar determines the validity or invalidity of an act or legal event. If one of the pillars in the event or legal action is not fulfilled, such legal shows or circumstances are invalid, and the status is "null and void." The conditions are beyond the nature of the law.

The pillars of Marriage in Islamic Law, according to MadzhabShafi' $i$, which is the grip of the majority of Indonesian Muslims and accommodated in Article 14 compilation of Islamic law, are prospective husband, future wife, guardian of Marriage, two witnesses, and ijabqabul'. Underlining one of the pillars of Marriage, namely the issue of marriage guardians and their urgency in a marriage, most scholars of fiqh argue that a woman should not marry herself or others. If he marries without a guardian, the Marriage is void or not sap as for the arguments put forward by the fiqh scholars, based on surat al-Baqarah verse 232 .

In Indonesia, for example, in the Compilation of Islamic Law, the guardian is one of the pillars of Marriage. Without a guardian, Marriage is not sap. Article 19 of the KHI states: 2"The guardian of marriage in marriage is a pillar that must be fulfilled for the bride-to-be who acts to marry her" Because this article places the guardian as one

\footnotetext{
${ }^{1}$ Imam Syaukani, Konstruksi Epistemologi Hukum Islam Indonesia dan Relevansinya Bagi Pembangunan Hukum Nasional, (Jakarta: Raja Grafindo Persada, 2006), p. 253.

${ }^{2}$ Ahmad Rofiq, Hukum Islam di Indonesia (Jakarta: Raja Grafindo Persada, 1998), 3, p. 83.
}

of the pillars of Marriage, then its existence must exist.Marriage is not considered valid if the pillars are not fulfilled. Because of the importance of the presence of a guardian in Marriage, article 23 of KHI seeks a guardian solution for women who do not have a guardian, or the guardian is reluctant to marry her:

In guardianship known as "wali mujbir," that is, through the right of ijbar, a guardian can marry his daughter or woman under his control into a marriage without his permission. The establishment of this right of ijbar, according to al-Shafi'i and other scholars, is based on his deep affection for his daughter. Therefore, al-Shafi'i only gives the right of ijbar to the father alone. Although in later developments, followers of al-Shafi' $i$ modified this concept by providing ijbar rights also to grandfathers. ${ }^{3}$

Looking at the political history of law in the era of independence, this began with the issuance of Law No. 1 of 1974 on Marriage and the birth of the Compilation of Islamic Law (KHI), it can be said that the peak achievement of Muslims in making Islamic law partly the substance of Islamic law (alAhwal al-Shakhshiyah / the family law) as positive law. ${ }^{4} \mathrm{KHI}$ is considered the only detail of Islamic sharia that the state has recognized and is the primary reference for resolving family law issues for Indonesian Islamic communities. Moreover, the presence of KHI on Indonesian earth is also expected to be a pedestrian bridge in minimizing khilafiyah disarmament in the matter of legal basis. ${ }^{5}$

${ }^{3}$ Muhammad bin Idris al-Syafi'i, al-Umm, (Bayrut: Dar al-Kutub al-'Ilmiyah, t.th), III, p. 18.

${ }^{4}$ Abdurrahman, Kompilasi Hukum Islam di Indonesia, (Jakarta: Akademika Pressindo, 1992), p. 20.

${ }^{5}$ Abul Khair, Telaah Kritis "Counter Legal Draft Kompilasi Hukum Islam (Reorientasi Fikih Hukum Keluarga Islam Indonesia), Jurnal Al-Rislalah, Vol. 4 , No.1 2016, p. 20 
Responding to the socio-political phenomenon of "strengthening the movement of Islamism," the CLD-KHI team is of the view that the demands for the formalization of Islamic sharia, in addition to not being in line with the national legal system, also create discrimination against non-Muslim citizens, which can ultimately shake the pillars of pluralism and democracy in the life of the nation based on Pancasila. This fear was used as the basis by the CLD-KHI team to compile a pluralist, democratic, humanist, and genderfair Islamic sharia script. ${ }^{6}$

From a deep study, the CLD-KHI team formulated that Marriage should be carried out on the principles of willingness (al-taradi), equality (al-musawah), justice (al-'is), good (al-maslahah), pluralism (al-ta'addudiyah), and democracy (al-dimuqratiyyah). ${ }^{7}$ As a logical consequence of this CLD-KHI version of the principle of Marriage, it has an impact on the equality of position between women and men in terms of ijab and Kabul, witness, 'iddah, nusyuz, mourning, referencing, giver, and recipient of dowry, livelihood, position in the household, minimum age of Marriage, and guardianship.

In terms of the pillars and conditions of Marriage, in the Draft Law on Islamic Marriage Law version CLD-KHI in Article 7 mentioned that: "Marriage is declared valid if it meets the following pillars: a) the prospective husband, b) the prospective wife, c) 2 witnesses, d) ijab and Kabul, and e) recording". In the second part of Article 8, Paragraph (1), it is stated that: "The future husband or wife may marry himself with the following requirements: a) be intelligent, b) be 21 years old, and c) mature/

${ }^{6}$ Tim Pengarusutamaan Gender Departemen Agama RI, Pembaruan Hukum Islam, (Jakarta: Counter Legal Draft Kompilasi Hukum Islam, 2004), p. 3.

${ }^{7}$ Article 4 of the Bill on Islamic Marriage Law version of CLD-KHI) capable/mature (Rashid / ah)”. Furthermore, in Paragraph (2), it is mentioned that: "For prospective husbands or wives who do not meet the requirements as in paragraph (1), then those who have the right to marry him are nasab guardians or guardians of judges" ${ }^{8}$

In line with the foremen above vision, perspective, and approach, CLD-KHI proposes Islamic principles that differ from KHI, and CLD-KHI makes the paradigm of Marriage, the relationship between husband and wife, and between child and parent, marriage administration, divorce, and reconciliation equal and democratic. In legal politics, CLDKHI places Islamic law under the framework of national law and changes in gender relations between members of Indonesian society after the New Order. Differences in gender relations, both at the national and global levels, require Islamic law following change. Therefore, according to the CLD-KHI team, the concept of guardianship in Marriage must be reviewed to only place a guardian for women when the bride-to-be is not legally capable. This also applies to prospective grooms when prospective grooms it is not legally capable.

The existence of fiqh rules on the urgency of guardians in Marriage, more specifically related to the presence of mujbir guardians in Marriage (although expressly not contained in Law No. 1 of 1974 on Marriage also in the Compilation of Islamic Law), which gives forced rights to the guardian, in this case, father and grandfather, it is fascinating to be confronted with the Counter Legal Draft compilation of Islamic Law (CLD-KHI) on guardianship in Marriage which later became a topic of Warm discussion.

Seeing that there is a discrepancy between the opinions of most fuqaha implied in the

\footnotetext{
${ }^{8}$ Articles 7 and 8 of the Bill on Islamic Marriage Law version CLD-KHI.
} 
Compilation of Islamic Law, and Law No. 1 of 1974 on Marriage on the one hand concerning the issue of guardianship, with the contents of the Counter Legal Draft compilation of Islamic Law on the other hand that carries the ideas and practices of democracy, pluralism, human rights, and justice and gender equality, this will undoubtedly result in the absence of legal certainty in the future, Then this is interesting to examine in the form of research, in addition, the concepts of Marriage carried by CLD-KHI tend to be contrary to Islamic sharia. Therefore it is necessary to conduct an in-depth study and even legal criticism.

Previous research related to walimujbir in CLD-KHI does explicitly not exist at all. However, there are several studies related to walimujbir written by M. Khoruddin with the title WaliMujbir. According to Imam Shafi'i (Maqasyid al-Sharia Review), this study aims to review the opinion of imam shafii' $i$ regarding walimujbir from the side of sharia maqasyid. ${ }^{9}$ Furthermore, research related to CLD-KHI was written by Lukman Budi Santoso with the title Of The Existence of The Role of Women as Heads of Families (Study of CLD-KHI and QiraahMubadalah). ${ }^{10}$

\section{Research Method}

The methods used in this research are qualitative methods with normative or doctrinal juridical approaches. While the data used in this study consists of primary data and secondary data, primary data is sourced from books or yellow books by imams of schools related to the issue of walimujbir as a

${ }^{9}$ M. Khoruddin, Wali Mujbir Menurut Imam Syafi'i (Tinjauan Maqashid al-Syariah), Al-Fikra: Jurnal Ilmiah Keislaman, Volume 18, Nomor 2, July-December 2019.

${ }^{10}$ Lukman Budi Santoso, Eksistensi Peran Perempuan Sebagai Kepala Keluarga (Telaah terhadap CLD-KHI dan Qiraah Mubadalah), Marwah: Jurnal Perempuan, Agama dan Jender, Volume 18, Nomor 2, 2019. representation of fuqaha views and laws and regulations applicable in Indonesia, especially Law No. 1 of 1974 on Marriage, Compilation of Islamic Law which was then confronted with counter legal draft compilation of Islamic law (CLD-KHI). While secondary data is sourced from journals and other supporting data in the form of books related to research and books and materials of Islamic Marriage. The data obtained will be collected in a study on mujbir guardians in fuqaha opinion, which is then accommodated in existing legislation in Indonesia, including Law No. 1 of 1974 on Marriage and Compilation of Islamic Law (KHI), then used to criticize one of the contents of the CLD-KHI Legal Draft Counter.

This research aims to find the concept of walimujbir in Marriage in the opinion of the majority fuqaha contained in the Compilation of Islamic Law (KHI) and Law No. 1 of 1974 on Marriage and criticism of Islamic law about guardians and their existence in Marriage contained in the Counter Legal Draft compilation of Islamic Law (CLD$\mathrm{KHI}$ ).

\section{Wali Mujbir Concept}

Choosing a soul mate is one of the principles of Marriage that often clashes with the guardian's rights. Some people assume that a soul mate for a girl is in the hands of parents, namely their father as a guardian. This is in the spotlight that in Islam, women's right in determining a partner is the full right of their guardian. ${ }^{11}$ The issue of guardians is one of the dynamics of the law that is very important discussed in the fikih munakahat. Indeed, there is a reasonably vigorous thought

${ }^{11}$ Niswatul Faizah, Konsep Wali Mujbir Iman Syafi'i dalam Perpektif Ham (Human Right), Jurnal Pro Justice: Kajian Hukum dan Sosial, Vol. 1 No. 2 2019, p. 11. 
debate about the position of the guardian in the marriage procession. The discussion about the role of the guardian of Marriage is not only related to the issue of the validity of one's Marriage. However, it also relates to the right to marry a person under his guardianship. It is also associated with the issue of licensing for people who will do Marriage.

This ijbar right cannot be waived by underage Marriage because in this case the guardian (father/grandfather) has the right to marry his daughter without having to get the consent or permission in advance of the daughter to be married, as long as she is not a widow. A father can marry his young and virgin daughter as long as he has not been unlicensed and there is no right to marry the girl if she has puberty. On the other hand, the father should not marry his young son. However, a daughter cannot be immediately sowed by her husband if she is too small so that she is old enough to have sex like a husband and wife.

In the current context of mujbir, guardians have the right to debate what else if faced with global issues such as gender. This concept is considered contrary to gender equality and justice. In other words, it is deemed to take away women's rights, especially in the ownership of ijbar, mujbir guardians have the right to marry their daughters even without the consent of the concerned, and there is a presumption that a woman is considered weak in acting and unable to make her own decisions.

The concept of gender is an inherent trait of men and women constructed socially and culturally. ${ }^{12}$ The basic assumption of liberal feminism is rooted in the view that freedom and equality are rooted in rationality and

\footnotetext{
${ }^{12}$ Mansor Fakih, Analisis Gender dan Transformasi Sosial, Cet I, (Yogyakarta: Pustaka Pelajar Offset, 1996), p. 8.
}

separation between the private and public worlds. The framework of liberal feminists in fighting for society's problems is focused on equal opportunity and equal rights for every individual, including women's options and rights.

Regarding liberal feminism, it appears that the struggle of liberal feminists primarily wants to free women from the oppression of gender roles, which are roles given to women because they are based on gender. This role justifiesproviding a lower place to women or even not being given a business at all.

For liberal feminism, efforts to achieve equality for women in politics, education, work and pursued through legal channels by reforming the existing system. For women to be emancipated and liberated from social confinement, liberal feminism advocates practicing androgyny (a term used to denote the division of equal roles in masculine and feminine characters simultaneously, which can refer to one of two related concepts of gender) in women and men. ${ }^{13}$

Based on the above exposure, in the wali mujbir, women's rights are neglected. The basic assumption that women are irrational, emotional, weak, etc., leads to the placement of women in roles considered less critical. Therefore it is necessary to re-present the concept of wali mujbir, which is regulated in Islam.

In guardianship known as "wali mujbir," that is, through the right of ijbar, a guardian can force his daughter or the woman under his control into a marriage without his permission. According to Imam al-Shafi'i, Imam Malik, Imam Ahmad, Ishaq, and Abi Layla established the right of ijbar based on

${ }^{13}$ Gadis Arivia, Filsafat Berperspektif Feminis, Cet I, (Jakarta Selatan: Yayasan Jurnal Perempuan, 2003), p. 99-100 
a hadith of the Prophet Muhammad (peace be upon him) narrated Abu Dawud of Ibn 'Abbas, namely:

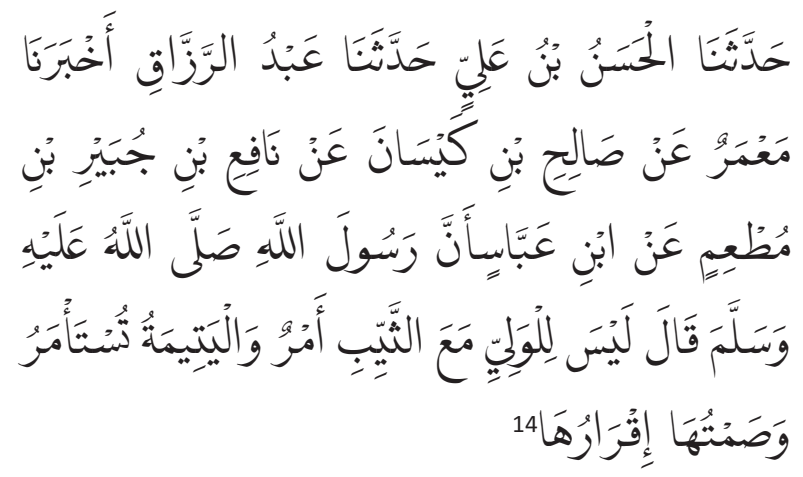

Hasan bin 'Aliy conveyed the hadith to us, 'Abd al-Razzaq conveyed to us, Mamar reported to us from Salih bin Kaysan from Nafi' bin Jubayr bin Mut'im from Ibn 'Abbas that the Prophet (peace be upon him) said, "There is no right of guardian to widowed women and orphans must be asked for his permission, silence is his consent. (HR. Abu Dawud).

Although there is an order asking permission or approval of girls to marry, al-Shafi'i considers that asking for a girl's consent is not a mandatory order (amruikhtiyarin la fardin). For in this hadith, widows and girls are distinguished. So that the Marriage of a girl who is forced without her permission is legal, if the father cannot marry without the girl's permission, then it is as if the girl is no different from the widow. But this hadith distinguishes between widows and girls. The widow is more entitled to her, as the hadith says:

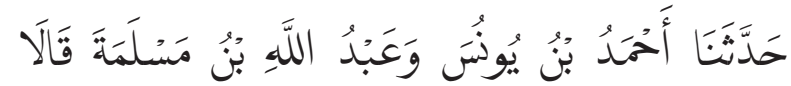

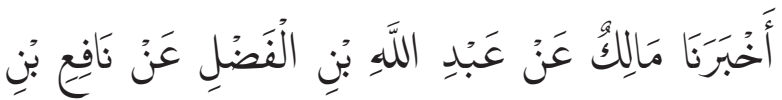

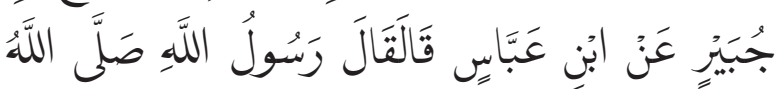

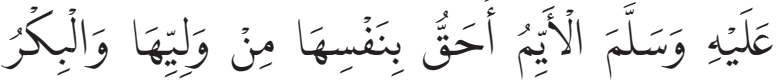

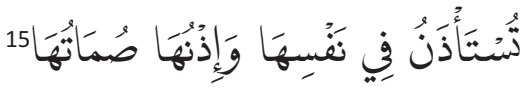

${ }^{14}$ Abi Dawud, Sunan Abi Dawud, p. 233.

${ }^{15}$ Abi Dawud, Sunan Abi Dawud, No. hadis 1795.
Ahmad bin Yunus and Abdullah bin Maslamah reported to us, both of whom said: "It has been reported to us, Malik from 'Abdillah bin al-Fadl of Nafi' bin Jubayr from Ibn 'Abbas, he said: The Prophet said: "The one who himself has more right to him than his guardian and the virgin woman is asked for permission about him and his permission is silence.." (HR. Abu Dawud).

Widows are more entitled to themselves than their guardians. Thus, he must be asked for approval. The Marriage imposed on him is void. In this regard, Imam al-Shafi'i reveals a rule:

$$
\text { كل ثيوبة ترفع الأجبار } 16
$$

"Every widow removes ijbar (compulsion)."

On the contrary, it is the guardian who is more entitled to the girl. So the guardian does not have to ask for approval to marry the girl. This is what is called 'wali mujbir.' The establishment of this right of ijbar, according to al-Shafi'i and other scholars, is based on his deep affection for his daughter. Therefore, alShafi'i only gives the right of $i j b a r$ to the father alone. Although in later development, ashab (followers) al-Shafi'i modified this concept by providing ijbar rights to grandfathers. ${ }^{17} \mathrm{~A}$ father is personified to care so much about his daughter's happiness. Because the girl has no experience living in a household, besides usually being embarrassed to find her partner, the scholars try to provide a means for the father to help his baby.

This Ijbar right cannot be waived by underage Marriage because, in this case, the guardian (father/grandfather) has the right to marry his daughter without having to get

${ }^{16}$ Ibn Rusyd, Bidayah al-Mujtahid wa Nihayah alMuqtashid (Semarang: Maktabah wa Matba'ah Thoha Putra, t.th), II, p. 5.

${ }^{17}$ Muhammad bin Idris al-Syafi'i, al-Umm (Bayrut: Dar al-Kutub al-'Ilmiyah, t.th, III, p. 18. 
the consent or permission in advance of the daughter to be married, as long as she is not a widow. A father can marry his young and virgin daughter as long as he has not been unlicensed, and there is no right to marry the girl if she has puberty. On the other hand, the father should not marry his young son. However, a daughter cannot be directly sexually assaulted by her husband if she is too small so that she is old enough to have sex like a husband and wife.

Scholars who allow guardians to marry their underage daughters are generally based on Abu Bakrra. Marry Siti 'Aisha ra., with the Prophet.

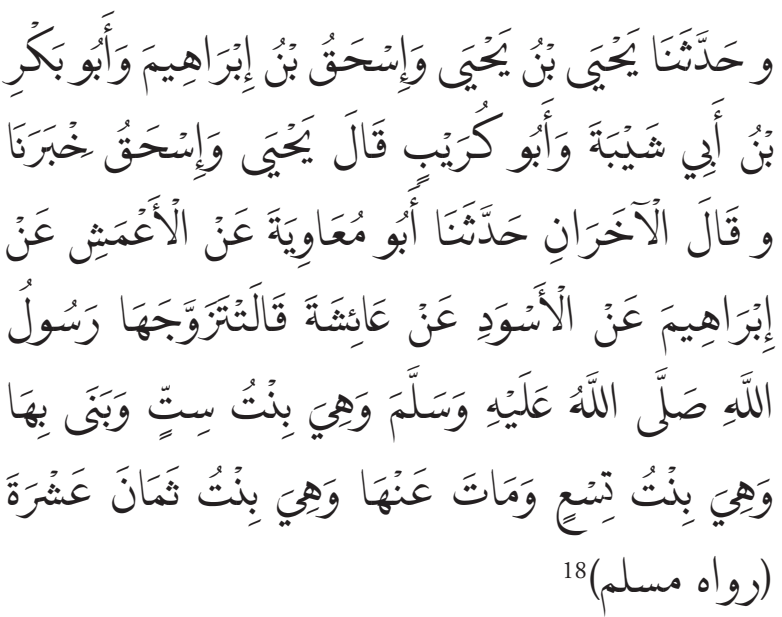

He told me Yahya bin Yahya, Ishaq bin Ibrahim, Abu Bakr and Abu Karib. Yahya and Ishaq have said: Have told us and said al-Akhrani: Have told me Abu Mu'awiyah from al A'masyi from al Aswad from 'Aisha ra. He said: The Prophet married me when I was six years old and lived with me at the age of 9, and he died when I was 18 years old. (HR. Muslim).

Abu Bakrra. He married 'Aisha to the Prophet (peace be upon him) as a child without his consent. For at such an age, his support cannot be considered perfect. However, regarding the Marriage of 'Aisha ra

${ }^{18}$ Abi al-Husayn Muslim bin Hajjaj al-Qushayri alNaysaburi, Sahih Muslim (Beirut: Dar al-Fikr, 1992), I, p. 650-651. with the Prophet Muhammad, some scholars argue that it is an exception or specificity for the Prophet himself as the Prophet (peace be upon him) was allowed to give more than four people whom his people should not follow. ${ }^{19}$

Another opinion states that the Marriage of the Prophet (peace be upon him) with 'Aisha was more motivated by da'wah and gave freedom to Abu Bakrra. Entered the house of the Prophet. ${ }^{20}$ However, the right of a father or grandfather can not necessarily be exercised at will. Ulama' Shafi'iyyah said that marrying underage boys required the existence of good (good interests). As for girls, several conditions are needed, among others:

- There was no real feud between the daughter and her guardian, her father or grandfather.

- There was no real hostility between her and her future husband.

- The husband-to-be must bekufu'(appropriatel equivalent).

- Husband-to-be can give a proper dowry.

Imam Syâfi'i further argued that a father might marry her without harming the child regarding an immature girl who is about 15 (fifteen) years old or has not had a period. On the contrary, a guardian should not force the Marriage of his daughter if it can harm or trouble the girl. As for the basis of ijbar rights in this context is the act of Abu Bakr in marrying his daughter, 'Aisha with the Prophet Saw. At that time 'Aisha was still six years old. In addition, it is also supported by the reason that all the affairs of small children are the responsibility of their father. ${ }^{21}$

${ }^{19}$ Mahmud Yunus, Hukum Perkawinan dalam Islam, (Jakarta: Hidakarya Agung, 1985), p. 69.

${ }^{20}$ Amir Syarifuddin, Ushul Fikih, Jilid I, (Jakarta: Prenada Media, 2008), III, p. 67

21 Khoiruddin Nasution, Hukum Perkawinan 1: Dilengkapi Perbandingan Undang-Undang Negara Muslim Kontemporer, (Yogyakarta: ACADEMIA dan TAZZAFA, 2005), p. 87-88. 
Further explanation related to the Marriage of adult girls (already 15 years old or who has experienced menstruation). There is a balanced right between the father and the girl in this case. Although the approval given by the girl is more of an option (ikhtiyar) is not a necessity (fard). Thus, the permission of the adult child is only mandatory. As for the Marriage of a widow, there must be express permission from the concerned. Therefore, a guardian who wants to marry a widow to a man he does not like can be rejected or annulled. This is based on the marriage case left by the Prophet because there was a widow who married her guardian to a person she did not like and was not asked for approval first.

About the context of the right of guardian ijbar, Imam Malik distinguishes the treatment of girls from widows. There is a difference between a father as a guardian and a guardian outside the father for girls. Father, as a guardian, mujbirentitled to force his daughter to marry through the right of ijbar. On the other hand, the guardian outside the father does not have the privilege of ijbar (wali gairu mujbir). It is said that the only person who can force a woman to marry is the father of his daughter and against the little boy, the master of his servant (i.mean the little servant/ immature), and the guardian of the orphan.

Other information also mentions that no one can force a woman to marry except the father of his daughter. The guardian outside the father can only match the girl if there is approval from the girl concerned. ${ }^{22}$ Regarding a widow, Imam Mâlik argued that there must first be firm consent from a widow before the implementation of the marriage agreement. In other words, widows are more entitled to determine their Marriage than their guardians.

${ }^{22}$ Khoiruddin Nasution, Hukum Perkawinan..., p. 86.
The reverse understanding indicates that the guardian has the right to consent to the girl's Marriage. Thus, the law of asking for the girl's permission in Marriage is only circumcision or as a refinement. The approval of his legal widow is mandatory. The widow's right to her guardian in Marriage is the right to support her guardian's perception and not in the context of marrying herself. As for who has the right to marry a widow remains the authority of his guardian. Thus, a widow cannot marry herself.

Regarding the provisions of the mujbir guardian in Marriage, most jurists, such as the Mâlikiyah, Syâfi'iyah, Hanabilah and Zahiriyah (except Hanafiyah) allow the guardian to exercise ijbar rights with various classifications and specific conditions. In this case, the use of ijbar rights is carried out by the mujbir guardian against his child and the person under his guardianship to marry even without being asked for their permission first. The cleric's opinion was one of them based on the Prophet's hadith about the actions of Abu Bakr who married his daughter 'Aisha r.a. with the Prophet who at that time, 'Aisha r.a. was still immature (aged about 6 years).

Although jumhur ulama allows the use of ijbar rights carried out by a guardian against his child or someone under his guardianship, ibnQayyim al-Jauziyyah argues that parents or guardians should not force their children or someone under his control to marry except with the consent and willingness of the child first. Although the parent or guardian has the power to marry off the child or person under his guardianship. However, it is not done if there is an element of coercion that causes the absence of willingness by the child in the framework of his Marriage. Ibn Qayyim alJauziyyah expressed his views as follows:

"Women girls who have been balig should not be forced into marital matters and 
should not be married except with her rida. In one of the narrations, this is the opinion of jumbur salaf, the school of Abû Haniffah and Ahmad in one of the narrations. This is in line with the law of the Prophet (saw), his commandments and prohibitions, the rules of sharia and the benefit of the people." 23

The need for the consent of a child in choosing a partner, as expressed by IbnQayyim al-Jauziyyah above, is based on the hadith about a girl's refusal to marry her guardian. ${ }^{24}$ Furthermore, IbnQayyim also strengthened his opinion by presenting other hadiths about widows who should not be forced to marry by their guardians. Based on the various hadiths above, IbnQayyim al-Jauziyyah stated that the use of ijbar rights should not be done by parents against their children. ${ }^{25}$

The existence of ijbar rights in Marriage is inseparable from the presence of mujbir guardians because only the mujbir guardian can use it. The right of ijbar can be defined as the right owned by the mujbir guardian to force his daughter who is under his guardianship to marry the man of his choice without the permission of the girl who is summarized or, in other words, the right to unilaterally determine the future husband for the girl under his guardianship.

According to Ibrahim Hosen, walimujbir is interpreted as a guardian who has the right to marry his virgin daughter without asking for his permission first, with the conditions set by sharia following the function of the

${ }^{23}$ Ibnu Qayyim al-Jauziyyah, Zâdul Mà ad fì Hadî Khairil, (Beirut: Dâr al-Kutûb al-Ilmiyah, 2007), Cet. II, p. 703.

${ }^{24}$ Hadis Riwayat Ibnu Mâjah Nomor 1875. See: Abû Abdullah Muhammad bin Yazid al-Qazwini Ibnu Mâjah, Ensiklopedia Hadis 8: Sunan Ibnu Mâjah, alih bahasa Saifuddin Zuhri, (Jakarta: Penerbit Almahira, 2013), Cet. I, p. 333.

${ }^{25}$ Abû Husein Muslim, Shahîh Muslim Juz II, (Beirut: Dâr al-Fikr, 2011), p. 650. father aims for the benefit of his child. So the granting of rights to the father to his daughter does not mean justifying forced Marriage. In understanding the two hadiths mentioned above, he uses the ushul fiqh rule from the aspect of language, namely mafhum mukhalafah and the type of mafhum nature. ${ }^{26}$

In essence Islam prohibits the coercion of women to marry, both against girls and widows with men they do not like, because Marriage is an eternal association and a husband and wife's communion. The eternal love and friendship will not be realized if the wife's willingness is not known before. Therefore the guardian must question the bride-to-be and ask for her consent. The marriage agreement that is carried out without the bride's willingness is not sap. Against the Marriage carried out by his guardian, he can demand cancellation because the purpose of Marriage itself is to build a happy family overwhelmed with love and compassion and the love of Allah SWT. This goal will be achieved when the bride and groom have known each other and like each other to hold a marriage bond.Mutual liking likes this in the form of the permission and approval of the parties who will perform the Marriage itself. Because the woman does not directly carry out "ijab," religion indicates permission and consent before Marriage. ${ }^{27}$

Law No. 1 of 1974 concerning Marriage has also been regulated about the conditions that must be met in Marriage, namely article 6 paragraph (1), which states that:

"Marriage must be based on the consent of both brides-to-be." 28

${ }^{26}$ Suansar Khatib, "MetodeI jtihad Ibrahim Hosen”, Jurnal Ilmiah Mizani, Vol. 2, No. 1 (2015), p. 79

${ }^{27}$ Kamal Muchtar, Asas-Asas Hukum Islam Tentang Perkawinan, cet. III (Jakarta: PT Bulan Bintang, 1993), p. 97

${ }^{28}$ Law of the Republic of Indonesia Number 1 of 1974 concerning Marriage and Compilation of Islamic Law and Its Explanation, (Bandung: Citra Umbara, 2007), p. 4 
In line with the Marriage Act, the Compilation of Islamic Law (KHI) also confirms in article 16 paragraph (1) dam (2), that:

1. Marriage is based on the approval of the bride-to-be.

2. The form of consent of the bride-to-be can be a firm and accurate statement with writing, oral or gestures but can also be silent in a sense as long as there is no strong rejection." 29

If a marriage is performed without the permission of the woman who is to marry, then the woman is given the right to choose whether she will continue her Marriage or reject the Marriage. WaliMujbir is a guardian who can force Marriage on persons under his guardianship; he does not need the permission or prior consent of the person under his control to carry out their Marriage.

Wali mujbir is the person responsible for this is a father and grandfather who act directly to do something. But in reality, the concept impacts women, namely causing resistance to violence in women. Equal rights and freedoms for men and women to choose a life partner with the consent of the blower. As dignified human beings, women have the right as their male siblings to select their own choice of the soul mate, and parents should give guidance and consideration.

In express, indeed Law No. 1 of 1974 on Marriage and Compilation of Islamic Law does not regulate the existence and legality of wali mujbir. But the provisions regarding guardians are set out in the Compilation of Islamic Law in great detail. Guardianship itself is the authority given to a person to do something legal as a representative for the

${ }^{29}$ Law of the Republic of Indonesia Number 1 of 1974 concerning Marriage and Compilation of Islamic Law and Its Explanation, p. 233 benefit and on behalf of a child who does not have both parents who are still alive, is not capable of doing legal acts. ${ }^{30}$

What has been formulated and excavated by the scholars of the Islamic jurisprudent school, dynamically reformulated in the form of Islamic legal legislation, namely the Compilation of Islamic Law that applies to Muslims in Indonesia, even the provisions regarding guardians regulated in the Compilation of Islamic Law are in its chapter, namely in Chapter XV and in several other articles. This shows that the status of guardians, especially marriage guardians in Indonesia, has been finalized. This is, of course, different from countries that adhere to certain schools, such as Saudi Arabia, Iran, Iraq, and various other Islamic worlds that are obedient and loyal to the views of the four primary schools.

\section{Guardians in CLD-KHI}

The pillars and conditions of Marriage in the Draft Law on Islamic Marriage Law VERSION CLD-KHI are contained in Articles 7 , and 8 mentioned that:

\section{Article 7}

"Marriage is declared valid when fulfilling the following pillars:
a. Husband-to-be.
b. future wife.
c. two witnesses.
d. ijab and kabul.
e. Recording.

Article 8

1. Prospective husbands or wives can marry themselves under the following conditions:

a. be healthy.

b. 21 years old.

c. mature/capable/mature (Rashidah)".

${ }^{30}$ Article 1 letter h Compilation of Islamic Law 
2. For prospective husbands or wives who do not meet the requirements as in Paragraph (1), then those who have the right to marry him are nasab guardians or guardian judges." 31

Based on his frame of mind, the CLDKHI team interprets Qur'anic verses and hadiths from the perspective of public interest (maslahah), local wisdom, maqasid al-shari'ah, and general logic. This can be seen from the principles of Islamic jurisprudence utilized by the team in formulating the concept of Islamic law. However, the team still needs a treasury of classics (yellow books) from various Islamic law universities. This means that all the rules of Islamic law in CLD-KHI are formulated from authoritative sources of Islam, the Qur'an and al-Sunnah, and the vocabulary of classical works (yellow book) by examining the needs, experiences, and traditions that live among members of Indonesian society, and Islamic civilization in general as well as Western civilization. The team's method of interpretation can be explained as follows:

1. The fundamental difference between the reasoning of CLD-KHI and that of KHI lies in their perspective and approach and the legal basis for the establishment of Islamic law. The members of the CLD-KHI team clearly stated that they take advantage of the perspectives of gender equality, pluralism, human rights, and democracy in formulating Islamic family law. This perspective will make sharia a public law accepted by all members of society make sharia matching for democracy. ${ }^{32}$

2. The results of reasoning match the interim regulations in Indonesia. It has a connection

\footnotetext{
${ }^{31}$ Articles 7 and 8 of the Bill on Islamic Marriage Law version CLD-KHI.

${ }^{32}$ Gender Mainstreaming Team of the Ministry of Religious Affairs, Pembaruan, p.3-4.
}

to the rule of law, which states that the rule of law made later must not conflict with the existing one. Before CLD-KHI was created, MPR had amended the 1945 constitution four times. ${ }^{33}$ An essential part of the amendments is that they put democracy, equality, and human rights in strategic positions. Several measures supporting these issues have also been issued, such as Law No. 7/1984 on the legalization of CEDAW (Convention on the Elimination of All Forms of Discrimination against Women), Law No. 39/1999 on Human Rights, Law No. 23/2002 on Child Protection, Law No. 23/2004 on Domestic Violence, Law No. 12/2005 on Legislation from ICCPR (International Covenant on Civil and Political Rights, Law No. 11/2005 on ICESCR (International Covenant on Economic, Social, and Cultural Rights) Law.

3. In the framework of this provision, CLD$\mathrm{KHI}$ is formulated in article form. Cld KHI adopts legal considerations under the idealistic vision of Islamic law. This vision consists of six points, "pluralism (ta'addudiyyah), nationality (muwatanah), upholding human rights (iqamat al-huquq al-insaniyyah), democracy (dimuqratiyyah), public benefits (maslahah), and gender equality (al-Musawah al-jinsiyyah). ${ }^{34} \mathrm{All}$ this inspired all the rules of Islamic law belonging to CLD-KHI.

In line with the aforemen above vision, perspective and approach, CLD-KHI proposes Islamic principles that differ from KHI, and CLD-KHI makes the paradigm of Marriage, the relationship between husband and wife,

${ }^{33}$ Tim Lindsey, "Indonesian Constitutional Reform: Muddling Towards Democracy," Singapore Journal of International \& Comparative Law (2002), p. 6.

${ }^{34}$ Gender Mainstreaming Team of the Ministry of Religious Affairs, Pembaruan, p. 25-29. 
and between child and parent, marriage administration, divorce, and reconciliation equal and democratic. In legal politics, CLDKHI places Islamic law under the framework of national law and changes in gender relations between members of Indonesian society after the New Order. Differences in gender relations, both at the national and global levels, require Islamic law following the change.

Therefore, according to the CLD-KHI team, the concept of guardianship in Marriage must be reviewed to only place a guardian for women when the bride-to-be is not legally capable. This also applies to prospective grooms when prospective grooms it is not legally capable.

Child protection campaigns are starting to intensify. This departs from the awareness of the importance of maintaining and maintaining children as the buds of the nation. In their hands lies the future of the country. Therefore, an environment is needed that is conducive to the development of their lives.

Currently, Indonesia has Law No. 7 of 1984 on Ratification of the Convention on the Elimination of All Forms of Discrimination against Women (otherwise known as the CEDAW Convention) and Law No. 23 of 2002 on Child Protection. In Law No. 7 of 1984 article 16 is stated:

States Parties shall make appropriate regulations to eliminate discrimination against women in all matters relating to Marriage and familial relations based on equality between men and women, and in particular shall ensure:

a) The same right to enter Marriage;

b) The same right to choose a husband freely and enter the Marriage only with free and complete consent.

Based on the above law, it is clear that the right to determine who the child's spouse,how, and when he will perform the Marriage is the child himself as a form of the child's human rights. While parents do not have the right to impose their child's will to marry someone unilaterally.

Law No. 23 of 2002 on Child Protection article 21 states: States and governments are obliged and responsible to respect and guarantee the human rights of every child regardless of ethnicity, religion, race, class, gender, ethnicity, culture and language, legal status of the child, the birth order of the child, and physical and/ or mental condition.

Often occurs in forced Marriage, the child becomes the aggrieved party. It is also triggered by the assumption that children do not have the right to freedom of choice of their own. The child is seen as an individual who does not have adequate understanding for his benefit. This causes some parties to feel legitimate to force someone as the child's life partner. One of the causes that are often a pretext is the validity of parents (men) to carry out forced Marriage (ijbar) against their daughters. Such a pretext has always been based on religious legitimacy.

The Qur'an and hadith have told us a lot about how the child's duty to his parents. One form of respect for children towards parents is that they must respect, do good, obey, and speak polite and polite words as the word of Allah Swt in the Qur'an, al-Isra, verse 23:

Your Lord has commanded you not to worship anything other than Allah, and you should do good to your parents. If one of them or both of them is further in keeping you, do not say to them 'ah' and do not yell at them and speak to them glorious words."

This is a form of love that parents give to their children. In the context of reciprocity, the child's return to his parents is an obligation to respect and glorify him. For the high love and sacrifice of parents, in a hadith stated: 


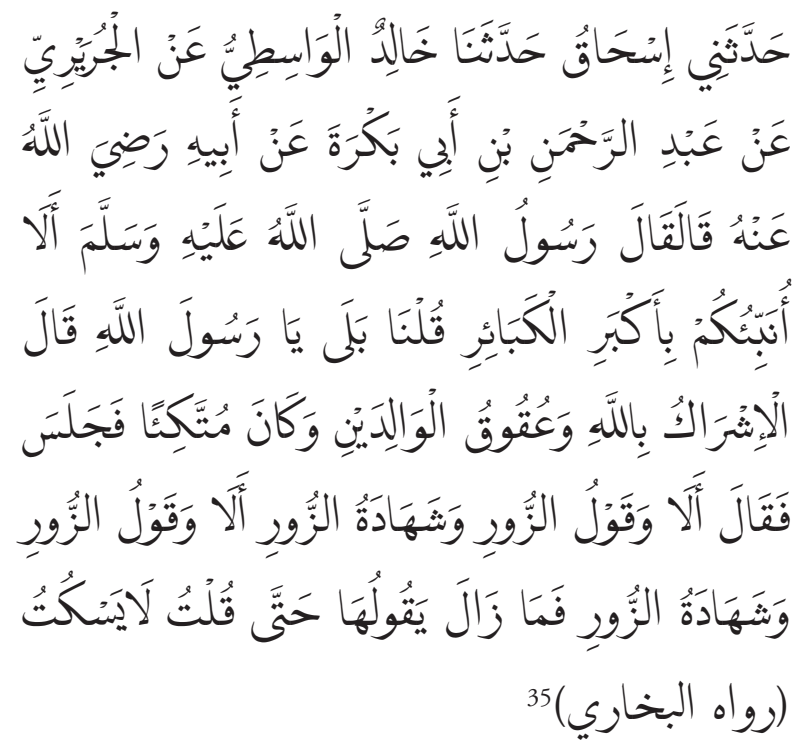

Ishaq reported to us, Khalid al-Wasitiy reported to us from al-Juraiyriy from 'Abd al-Rahman bin AbiBakrah from his father r.a. said he, had said the Messenger of Allah, "Shall I show you great sins, we answered: yes O Messenger of Allah." He said, "To keep God, disobey both parents." He stood up leaning back, then sat down and said, "Know the false words and false witnesses." (HR. al-Bukhari)

Based on that affection, the emergence of a mujbir guardian who has the right to be forced to marry his child. If it is true that the parent wants to pour out his affection, then he cannot force the will on his child to do something contrary to his benefit. Vice versa, the child will not easily oppose parents if he wants to pay his respects to parents. So this is a reciprocal relationship between the child and the parents. As imam Shaâfi'i above, an immature girl may be married by her father without harming the child. On the contrary, a guardian should not force the Marriage of his daughter if it canbreak or trouble the girl. This indicates that the father's right does not necessarily force his child to marry, but the request of a father also has a limit, that is, as long as the child is not harmed.

\footnotetext{
${ }^{35}$ Al-Bukhari, al-Bukhari, IV, p. 48.
}

In Islam men and women are equal in the field of piety but men and women are not equal in the area of Marriage, this is because in the lot of marriage men have more significant and more severe obligations and responsibilities than women, therefore, men can marry themselves while women must marry by their guardians. While in cld KHI men and women are equal in all fields including in the area of marriage women can marry themselves without Marriage by a guardian and men who can match themselves without a guardian.

Wali mujbir has the right to marry a girl under her guardianship without the woman's permission. In contrast, in cld KHI walimujbir has no right to force her child to perform the Marriage desired by her father without seeking the consent of the woman under his guardianship, if a guardian marries the woman under his control without the woman's permission, This is considered to deprive women of rights or freedoms that are contrary to the gender theory on which the cld KHI is based itself.

\section{Legal Criticism of CLD KHI}

In Islamic treasures, the right of ijbar has become a polemic in itself. Fiqh experts differ in their response. According to imam Malik, founder of the Maliki School, a father has the right to force his daughter (Ijbar's request) to marry, and this right belongs only to a father. It is said that the only person who can force women to marry is the father of the daughter and to the little boy, the master of his servant (who is immature), and the guardian of the orphan. Guardians outside the father may only marry if there is approval from the girl concerned. There is more power for the guardian in terms of consent on the Marriage of his daughter, Imam Malik based 
on a hadith "'al-ayyi muahaqqu binafsiha min waliyiha". This conclusion is drawn from the contrary understanding that widows are much more entitled to give consent to their Marriage. Therefore, the law of asking for a girl's permission in Marriage is sunnah rather than obligatory. ${ }^{36}$

IbnQudamah from the Hambali school claimed that scholars agreed on the guardian's right to marry an immature girl, whether the woman concerned likes it or not, on condition that it is sekufu. Even IbnQudamah himself argued that a father has the right to force his daughters, whether adults or those who are not, to marry a man as good as the woman is not happy. Still in the same way, the basis for marrying an immature girl is al-Talaq (65):4). In principle, this verse speaks of the time of 'iddah of a woman who has not menstruated or a woman who has broken her period. The simple logic is that iddah appears because of talaq, and talaq appears because of Marriage. Implicitly this verse indicates the permissible for a woman who has not menstruated (immature) to marry. While the basis of hadith may marry silly women, according to Ibn Qudamah is the act of the Prophet who married 'Aisha when he was seven years old and had sexual relations after the age of nine years. Scholars differ regarding wali mujbir, but not necessarily with western ideology as offered by thecld KHI team.

The idea offered by the CLD KHI team does not match the Islamic rules derived from the Qur'an, Hadith and Islamic legal traditions adopted by the majority of Muslims in Indonesia. The CLD-KHI point of view is subjective, as it corresponds only to the nature and character of team members. Its vision and mission consists of pluralism, democracy, human rights, gender equality, emancipation,

${ }^{36}$ Khoiruddin Nasution, Hukum Perkawinan..., p. 244 humanism, inclusivity, deconstruction of sharia, and others. CLD-KHI was formulated by a team that utilizes several approaches such as gender, pluralism, human rights, and democracy. The unit does not refer to the methodology of Islamic law, which is clearly stated by the team. The group claims to always refer to maqashid al-shariah as the basis, but the formulation of CLD-KHI is contrary to maqashid al-shariah. In addition CLD-KHI criticizes several points of view: First the Qur'an and Hadith should be interpreted in line with the logic and tradition and social context of society. The Qur'an and Hadith must be understood from the perspective of its maqashid (purpose) to realize the public interest. ${ }^{37}$

CLD-KHI proposes ideas on renewing Islamic family law that are different from the previous ones. The CLD-KHI team states that the formulation of ideas is based on the interpretation of the Qur'an, Hadith, and the opinions of scholars taking into account the public interest, maqâsyid al-shariah, public logic, and local wisdom. Some perspectives include democracy, pluralism, human rights and justice and gender equality. This perspective is not purely from Islamic law derived from the Qur'an and hadith. Moreover, as a set of alternative ideas, CLD-KHI seems "surprising" because it differs and even contradicts the general understanding of Islamic teachings and practices, especially Marriage. The concept in CLD-KHI differs from general practice and textual meanings of the Qur'an and Hadith.

In the context of legislation, it seems that CLD-KHI "failed" to convince the Government, the House, and majority Muslim figures, even making the relationship between muslim liberals and conservatives wrong because the

37 Huzaemah Tahido Yanggo, Kontroversi Revisi Kompilasi Hukum Islam, (Jakarta: Adelina, 2005), p. 7-9. 
idea belongs to CLD-KHI has angered Muslim conservatives, because the ideas proposed by CLD-KHI are sensitive issues that protest religious conscience and understanding of Islamic teachings such as polygamy, Marriage for a certain period allowed, Marriage is different religions and so on. CLD-KHI is not a product of Islamic law but a product of secular ideology, CLD-KHI is like a "cancer cell" which is very dangerous because it is a way of thinking and ideological paradigm equipped with political actions to keep Muslims away from the Qur'an and hadith.

In essence, the paradigm of Islamic family law versions of KHI and CLD-KHI in general tends to be paradoxical. The two have pretty striking legal differences due to differences in perspective and approach used. CLD-KHI emphasizes the philosophy of pluralism, gender equality, human rights, and democracy freely, so that the controversial ideas are visible, not only in matters of guardians, but related to dowry, witnesses, iddah, Marriage of different religions and heirs, the offer is very thick with liberal ideas and tends to conflict with jurisprudence. While KHI departs from the maqasid alsyariah approach with the use of the established UshulFikih methodology, so that the laws are more moderate although it tends to smell classic, but adhere to the rules and methods of understanding Islamic law that mu'tabarah and comprehensive so that it will better guarantee the presence of legal conclusions that are more following the intentions of sharia.

\section{Conclusion}

From the above exposure, it can be concluded that the mujbir guardian is a person who has the right to marry a woman who is under his guardianship without the need for permission from the woman, namely The Father. However, the rights that fathers have must consider the good of women. This means that the forced rights that fathers have havehave limits. In the Compilation of Islamic Law, the existence of guardians in Marriage is domiciled as a pillar of Marriage, this is because KHI adopts Islamic jurisprudent that mu'tabarah. This provision is different from the CLD-KHI formula which offers that a guardian is not required in a marriage (article 7 CLD-KHI). The formulation of the renewal of Islamic family law offered by CLD-KHI is based on the interpretation of the Qur'an, Hadith, and opinions of scholars taking into account public interest, public logic, and local wisdom and based on several perspectives such as democracy, pluralism, human rights, justice, gender equality and western ideology. The ideas of CLD-KHI are different and even contrary to the general understanding of Islamic teachings and practices, especially about Marriage. Ideas in CLD-KHI tend to differ from general practice and textual meanings of the Qur'an and Hadith.

\section{References}

Abdurrahman. Kompilasi Hukum Islam di Indonesia, Jakarta: Akademika Pressindo, 2002.

Arivia, Gadis. Filsafat Berperspektif Feminis, Jakarta: Yayasan Jurnal Perempuan, 2013.

Bukhâri, Abu Abdillah Muhammad bin Ismail al-. Shahîh al-Bukhâri, Beirut: Dâr al-Fikr, 2006.

Djubaidah, Neng. Pencatatan Perkawinaan dan Perkawinan Tidak Dicatat Menurut Hukum Tertulis di Indonesia dan Hukum Islam, Jakarta: Sinar Grafika, 2015.

Faizah, Niswatul. "Konsep Wali Mujbir Imam Syafi'i dalam Perpektif Ham (Human Right)", Jurnal Pro Justice: Kajian Hukum dan Sosial, Vol. 1, No. 2, 2019.

Fakih, Mansor. Analisis Gender dan Transformasi Sosial, Yogyakarta: Pustaka Pelajar Offset, 2006. 
Jauziyyah, Ibnu Qayyim al-. Zâdul Maad fì Hadî Khairil Beirut: Dâr al-Kutûb al-Ilmiyah, 2007.

Khair, Abul. "Telaah Kritis "Counter Legal Draft Kompilasi Hukum Islam (Reorientasi Fikih Hukum Keluarga Islam Indonesia)", Jurnal Al-Rislalah, Vol. 4, No.1, 2016.

Khatib, Suansar. "Metode Ijtihad Ibrahim Hosen", Jurnal Ilmiah Mizani, Vol. 2, No. $1,2015$.

Khoruddin, M. "Wali Mujbir Menurut Imam Syafi'i (Tinjauan Maqashid al-Syariah)”, AlFikra: Jurnal Ilmiah Keislaman, Volume 18, Nomor 2, Juli-Desember 2019.

Lestari, Novita. "Problematika Hukum Perkawinan di Indonesia", Jurnal Ilmiah Mizani, Vol. 4, No. 1, 2017

Mâjah, Abû Abdullah Muhammad bin Yazid alQazwini Ibnu. Ensiklopedia Hadis 8: Sunan Ibnu Mâjah, Jakarta: Penerbit Almahira, 2010.

Muttaqin, Imamul. "Studi Analisis terhadap Pendapat KH. MA. Sahal Mahfud tentang Wali Mujbir", Al-Hukama', Vol. 2, No. 1, Juni 2012.

Nasution, Khoiruddin. Hukum Perkawinan 1: Dilengkapi Perbandingan Undang-Undang Negara Muslim Kontemporer, Yogyakarta: ACAdeMIA dan TAZZAFA, 2015.

Naysaburi, Abi al-Husayn al-. Muslim bin Hajjaj al-Qushayri. Sahih Muslim Beirut: Dar al-Fikr, 1992.

Rasyid, Ahmad. "Pemikiran ibnu Qayyim al-Jauziyyah tentang Wali Mujbir dalam Pernikahan (Perspektif Hak Asasi Anak)", Jurnal Studi Agama dan Masyarakat, Vol. 12, No. 2, 2016.
Rofiq, Ahmad. Hukum Islam di Indonesia, Jakarta: Raja Grafindo Persada, 2008.

Rusyd, Ibn. Bidayah al-Mujtahid wa Nihayah al-Muqtashid, Semarang: Maktabah wa Matba'ah Thoha Putra, t.th.

Santoso, Lukman Budi. "Eksistensi Peran Perempuan Sebagai Kepala Keluarga (Telaah terhadap CLD-KHI dan Qiraah Mubadalah)", Marwah: Jurnal Perempuan, Agama dan Jender, Vol. 18, Nomor 2, 2019.

Syafi'i, Muhammad bin Idris al-. al-Umm, Beirut: Dar al-Kutub al-'Ilmiyah, t.th.

Syarifuddin, Amir. Ushul Fikih, Jakarta: Prenada Media, 2008.

Syaukani, Imam Konstruksi Epistemologi Hukum Islam Indonesia dan Relevansinya Bagi Pembangunan Hukum Nasional, Jakarta: Raja Grafindo Persada, 2016.

Tim Pengarusutamaan Gender Departemen Agama RI, Pembaruan Hukum Islam, Jakarta: Counter Legal Draft Kompilasi Hukum Islam, 2004.

Tim Lindsey, "Indonesian Constitutional Reform: Muddling Towards Democracy," Singapore Journal of International \& Comparative Law 2002.

Undang-Undang Republik Indonesia Nomor 1 Tahun 1974 Tentang Perkawinan dan Kompilasi Hukum Islam Beserta Penjelasannya, Bandung: Citra Umbara, 2007.

Yanggo, Huzaemah Tahido. Kontroversi Revisi Kompilasi Hukum Islam, Jakarta: Adelina, 2011. 